Research article

\title{
Expression of tissue inhibitor of matrix metalloproteinases (TIMP)-3 protein in invasive breast carcinoma: Relation to tumor phenotype and clinical outcome
}

\author{
Eleni Mylona ${ }^{1}$, Christina Magkou², loanna Giannopoulou1, George Agrogiannis ${ }^{1}$, Sofia Markaki ${ }^{3}$, \\ Antonios Keramopoulos ${ }^{3}$ and Lydia Nakopoulou ${ }^{2}$
}

\author{
1Department of Pathology, School of Medicine, National and Kapodistrian University of Athens, 75 Mikras Asias Street, Goudi, GR-115 27 Athens, \\ Greece \\ 2Department of Pathology, Attikon Hospital, 1 Rimini Street, GR-124 62 Chaidari, Athens, Greece \\ 3Department of Pathology, Alexandra Hospital, 80 Vasilissis Sofias Street, GR-115 28 Athens, Greece \\ Corresponding author: Lydia Nakopoulou, Inakopou@cc.uoa.gr \\ Received: 15 Jun 2006 Revisions requested: 17 Jul 2006 Revisions received: 28 Jul 2006 Accepted: 10 Oct 2006 Published: 10 Oct 2006 \\ Breast Cancer Research 2006, 8:R57 (doi:10.1186/bcr1607) \\ This article is online at: http://breast-cancer-research.com/content/8/5/R57 \\ (c) 2006 Mylona et al.; licensee BioMed Central Ltd. \\ This is an open access article distributed under the terms of the Creative Commons Attribution License (http://creativecommons.org/licenses/by/2.0), \\ which permits unrestricted use, distribution, and reproduction in any medium, provided the original work is properly cited.
}

\begin{abstract}
Introduction Our aim was to study the expression pattern of tissue inhibitor of metalloproteinases (TIMP)-3 protein in invasive breast carcinoma, and its clinicopathological and prognostic value as well as its relation to markers indicative of the tumor phenotype.

Methods Immunohistochemistry was performed on paraffinembedded tissue specimens from 173 invasive breast carcinomas to detect the proteins TIMP-3, estrogen receptor (ER), progesterone receptor, p53, c-erbB-2, topoisomerase Il $\alpha$ and $\mathrm{Bcl}-2$.

Results TIMP-3 protein was immunodetected in the cytoplasm of the malignant cells and the peritumoral stroma, as well as in in situ carcinoma and normal epithelium. Reduced expression of TIMP-3 protein within cancer cells was correlated with carcinomas of high nuclear and histological grade $(p=0.032$ and $p=0.015$, respectively), and low $\operatorname{ER}$ expression ( $p=$ 0.053). Moreover, TIMP-3 immunopositivity was inversely correlated with the expression of $p 53$ and topoll $\alpha$ proteins $(p=$
\end{abstract}

0.002 and $p=0.008$, respectively), whereas it was positively associated with Bcl-2 expression $(p=0.020)$. Reduced expression of TIMP-3 protein within cancer cells was found to have an unfavorable impact on disease-free survival $(p=0.052)$ in the entirety of the patient population, as well as in both subgroups of lymph-node-positive and mutant-p53-negative patients ( $p=0.007$ and $p=0.037$, respectively). Stromal localization of TIMP-3 protein was found to have no clinicopathological or prognostic value.

Conclusion This is the first immunohistochemical study to show that TIMP-3 protein within cancer cells is associated with tumor phenotype. Reduced expression of TIMP-3 protein within cancer cells was found to correlate with an aggressive tumor phenotype, negatively affecting the disease-free survival of both subgroups of lymph node-positive and mutant-p53-negative patients.

\section{Introduction}

Matrix metalloproteinases (MMPs) consist of a family of proteases that have a major role in the remodeling and turnover of the extracellular matrix, which is involved in many physiological and pathological conditions including tumor growth and metastasis [1]. Tissue inhibitors of metalloproteinases (TIMPs) are natural MMP inhibitors and impede the proteolytic activity of MMPs by forming noncovalent 1:1 stoichiometric com- plexes [2]. Disruption of the balance between MMPs and TIMPs may influence invasion and metastasis of cancer and may thus modify patient outcome [1]. However, TIMPs exhibit several other biological functions in addition to the inhibition of active MMPs. These include the regulation of pro-MMP activation, tumor angiogenesis, cell growth and apoptosis [3]. 
Breast Cancer Research Vol 8 No 5 Mylona et al.

Table 1

Correlation of TIMP-3 protein expression with clinicopathological parameters and various biological markers.

\begin{tabular}{|c|c|c|c|c|c|c|c|}
\hline \multirow[t]{3}{*}{ Parameter } & \multirow[t]{3}{*}{ Total } & \multicolumn{6}{|c|}{ Preserved expression } \\
\hline & & \multicolumn{3}{|c|}{ TIMP-3 within cancer cells } & \multicolumn{3}{|c|}{ Fibroblastic TIMP-3 } \\
\hline & & $n$ & $\%$ & $p$ & $n$ & $\%$ & $p$ \\
\hline \multicolumn{8}{|l|}{ Menopausal status } \\
\hline Before & 52 & 19 & 36.5 & NS & 25 & 48.1 & NS \\
\hline After & 115 & 41 & 35.7 & & 53 & 46.1 & \\
\hline \multicolumn{8}{|l|}{ Histological type } \\
\hline Ductal & 133 & 46 & 34.6 & NS & 61 & 45.9 & NS \\
\hline Lobular & 33 & 14 & 42.4 & & 17 & 51.5 & \\
\hline \multicolumn{8}{|l|}{ Histological grade } \\
\hline 1 & 21 & 12 & 57.1 & 0.015 & 12 & 54.5 & NS \\
\hline 2 & 98 & 36 & 36.7 & & 44 & 44.9 & \\
\hline 3 & 43 & 9 & 20.9 & & 19 & 44.2 & \\
\hline \multicolumn{8}{|l|}{ Nuclear grade } \\
\hline 1 & 58 & 28 & 48.3 & 0.032 & 27 & 46.6 & NS \\
\hline 2 & 55 & 19 & 34.5 & & 25 & 44.6 & \\
\hline 3 & 53 & 13 & 24.5 & & 26 & 49.1 & \\
\hline \multicolumn{8}{|l|}{ Tumor size } \\
\hline$<2$ & 39 & 19 & 48.7 & NS & 20 & 51.3 & NS \\
\hline 2 to 5 & 101 & 35 & 34.7 & & 43 & 42.2 & \\
\hline$>5$ & 26 & 6 & 23.1 & & 15 & 57.7 & \\
\hline \multicolumn{8}{|l|}{ LN status } \\
\hline Not infiltrated & 65 & 24 & 36.9 & NS & 30 & 45.5 & NS \\
\hline Infiltrated & 100 & 36 & 36.0 & & 48 & 48.0 & \\
\hline \multicolumn{8}{|l|}{ Stage } \\
\hline 1 & 29 & 13 & 44.8 & NS & 15 & 51.7 & NS \\
\hline 2 & 108 & 40 & 37.0 & & 47 & 43.1 & \\
\hline 3 & 28 & 7 & 25.0 & & 16 & 57.1 & \\
\hline \multicolumn{8}{|l|}{ ER status } \\
\hline Negative & 75 & 21 & 28.0 & 0.053 & 35 & 46.7 & NS \\
\hline Positive & 91 & 39 & 42.9 & & 43 & 46.7 & \\
\hline \multicolumn{8}{|l|}{ PR status } \\
\hline Negative & 84 & 28 & 33.3 & NS & 40 & 47.6 & NS \\
\hline Positive & 82 & 32 & 39.0 & & 38 & 45.8 & \\
\hline \multicolumn{8}{|l|}{ p53 status } \\
\hline Negative & 118 & 51 & 43.2 & 0.002 & 57 & 47.9 & NS \\
\hline Positive & 46 & 8 & 17.4 & & 19 & 41.3 & \\
\hline \multicolumn{8}{|l|}{ Bcl-2 status } \\
\hline Negative & 54 & 16 & 29.6 & 0.02 & 29 & 53.7 & NS \\
\hline Positive & 79 & 40 & 50.6 & & 41 & 51.3 & \\
\hline \multicolumn{8}{|l|}{ c-erbB-2 status } \\
\hline Negative & 62 & 18 & 29.0 & NS & 25 & 39.7 & NS \\
\hline
\end{tabular}


Table 1 (Continued)

Correlation of TIMP-3 protein expression with clinicopathological parameters and various biological markers.

$\begin{array}{llllll}\text { Positive } & 104 & 42 & 40.4 & 53 & 51.0\end{array}$

ER, estrogen receptor; LN, lymph node; NS, not significant; PR, progesterone receptor; TIMP, tissue inhibitor of metalloproteinases.

TIMP-3 is one of the four known TIMPs (TIMP-1, TIMP-2, TIMP-3 and TIMP-4). It is known to be tightly bound to the matrix through interaction with heparan sulphate [4] The gene encoding TIMP-3 is a cell-cycle-regulated gene [5] whose promoter has been shown to be regulated by cell-cycle-related factors such as p53 [6]. In vitro studies have shown that TIMP3 can suppress invasion [7-9] and may either promote [10] or inhibit $[7,11]$ cell growth as well inducing apoptosis in cancerous [8,9,11,12] and non-cancerous [7] cells. Specifically, the latter is associated with death receptor modulation [12,13] and type II apoptotic pathway activation [12]. Interestingly, at least in the mouse, it has been demonstrated that the absence of TIMP-3 is important in regulating apoptosis in physiological processes [14]. Moreover, delivery of TIMP-3 to tumor xenografts has confirmed its tumor suppressive activity $[11,15]$. Studies on silencing of TIMP-3 by gene methylation also suggested a tumor suppression role in several malignancies [16].

TIMP-3 expression has been detected in several cancer types, including esophageal [17,18], colorectal [19], endometrial [20] and prostatic [21] cancer. However, in breast cancer, TIMP-3 mRNA was found by in situ hybridization to be expressed predominantly in the peritumoral stroma [22], whereas its clinicopathological and prognostic value has been evaluated in relation to the expression levels of TIMP-3 mRNA and measured by methods that did not distinguish the cancerous from the stromal origin of the transcripts [23,24].

The purpose of the present study was to investigate the expression pattern of TIMP-3 protein in invasive breast carcinoma to determine the clinicopathological and prognostic value of its various localizations and their relation to the tumor's phenotype through their association with biological indicators, such as the cell cycle-related proteins p53 and topoisomerase Il $\alpha$ (topoll $\alpha$ ), c-erbB-2 and the anti-apoptotic protein Bcl-2.

\section{Materials and methods Patients and samples studied}

A total of 173 paraffin blocks with tumor samples were available from patients with resectable breast cancer, who had undergone surgery. We selected only women with histologically proven, clearly invasive breast carcinomas, regardless of their initial stage, in whom axillary lymph node dissection had been performed and who had all their resected materials studied histologically. The patients were aged from 25 to 86 years (mean 56.89 years). None of them had received radiation or chemotherapy preoperatively. The material acquired from them was used in research after informed consent had been obtained.

Routine histological examination was performed with hematoxylin-eosin staining. All carcinomas were classified in accordance with the criteria of the World Health Organization [25] and were recorded as invasive ductal or invasive lobular. The combined histological grade (1,2 or 3 ) of infiltrating ductal carcinoma was obtained according to a modified ScarffBloom-Richardson histological grading system with guidelines as suggested by Nottingham City Hospital pathologists [26]. Nuclear grading was based on nuclear pleomorphism. Staging at the time of diagnosis was based on the TNM system [27]. Tumor size (less than $2 \mathrm{~cm}, 2$ to $5 \mathrm{~cm}$, more than 5 $\mathrm{cm})$ and lymph node status were evaluated separately. The clinicopathological characteristics of the series are shown in Table 1. During the immunohistochemical procedure some specimens were destroyed, whereas others were considered to have too little tissue to be evaluated. The samples that were finally included in the statistical evaluation therefore numbered 167.

Follow-up was available for 166 patients, of whom 39 died of breast cancer and 109 had a recurrence. Mean survival time was 96.7 months (range 5 to 135 months) and median survival time was 111 months. Patient outcome was defined as disease-specific overall survival and recurrence-free survival, from surgery. All patients received conventional postoperative treatment depending on the extent of the disease, including radiation therapy and medical antiestrogen therapy, when indicated. Premenopausal patients with axillary involvement were treated with six courses of adjuvant chemotherapy.

\section{Immunohistochemistry}

Immunohistochemical staining for TIMP-3 was performed on formalin-fixed paraffin sections $4 \mu \mathrm{m}$ thick after heating overnight at $37^{\circ} \mathrm{C}$ and subsequent deparaffinization in xylene and rehydration through graded alcohols. After the quenching of endogenous peroxidase activity with $0.3 \%$ hydrogen peroxide in Tris-buffered saline for 30 minutes, we proceeded to microwave-mediated antigen retrieval in $10 \mathrm{mM}$ citrate buffer (pH 6.0) at $750 \mathrm{~W}$ for 15 minutes (three cycles, 5 minutes each). After rinsing with Tris-buffered saline, normal horse serum was applied for 30 minutes to block non-specific antibody binding. Subsequently, sections were incubated overnight at $4^{\circ} \mathrm{C}$ with the primary antibodies. A two-step technique (Envision; Dako, Glostrup, Denmark) was used for visualization, with diaminobenzidine as a chromogen. Finally, sections were counterstained with hematoxylin and mounted. 

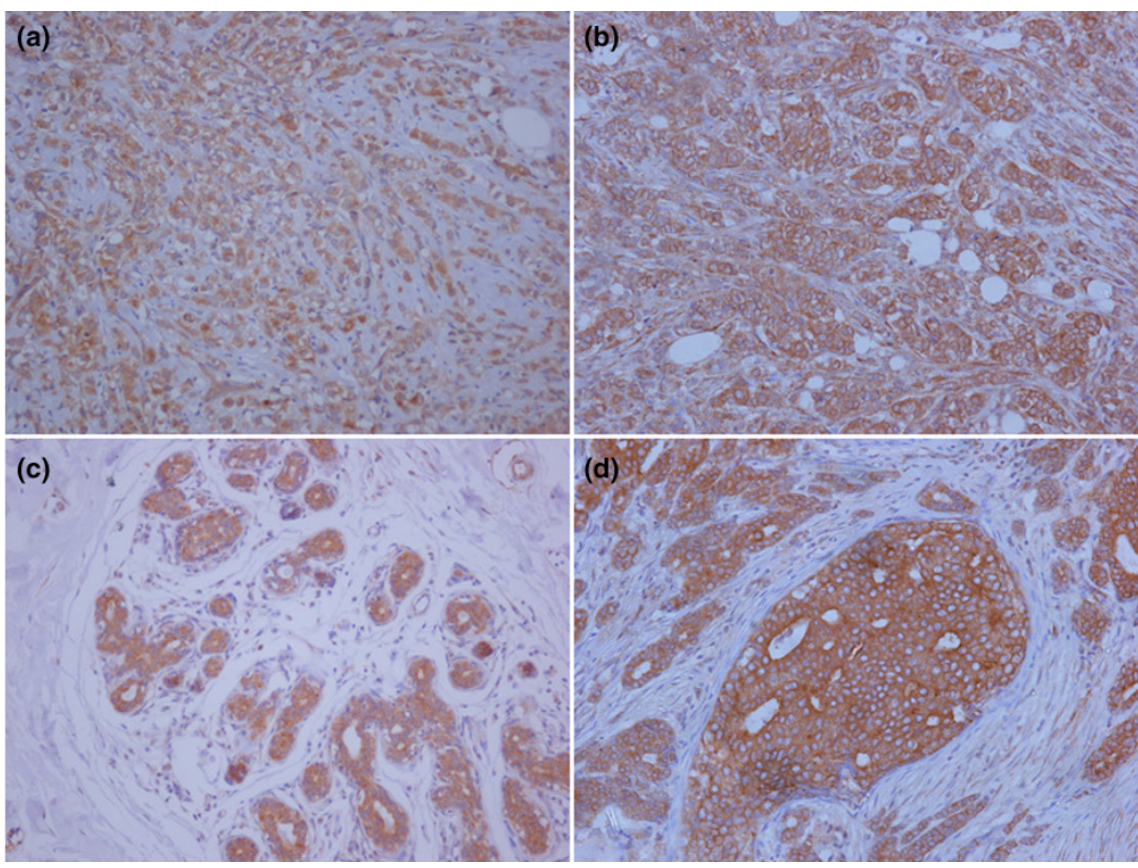

TIMP-3 protein expression in breast cancer and normal epithelium. The micrographs show tissue inhibitor of metalloproteinases (TIMP)-3 in the cytoplasm of a lobular carcinoma (a), both the cancer cells and peritumoral stroma of a ductal carcinoma (b), in situ carcinoma (c) and normal epithelium (d). Envision/horseradish peroxidase staining; original magnification $\times 200$.

A rabbit polyclonal antibody against the $C$ terminus of human TIMP-3 (no. RB-1541; Neomarkers, Fremont, CA, USA) was used at a dilution of 1:70. For the detection of estrogen receptor (ER) and progesterone receptor (PR), p53, c-erbB-2, Bcl2 and topoisomerase Il $\alpha$ proteins we used the following antibodies overnight, in a process similar to the aforementioned: anti-ER, clone 1D5 (dilution 1:450; Dako); anti-PR, clone IA6 (dilution 1:150; Dako); anti-p53, clone BP 53.12.1 (dilution 1:50; Oncogene, Cambridge, MA, USA); anti-c-erbB-2, clone CB11 (dilution 1:150; Biogenex, San Ramon, CA, USA); antiBcl-2, clone 124 (dilution 1:120; Dako, Glostrup, Denmark); and anti-topoll $\alpha$, clone JH2.7 (dilution 1:100; Biocare Medical, Walnut Creek, CA, USA).

\section{Evaluation of immunohistochemistry}

Evaluation of the immunohistochemical staining was performed independently by two pathologists through light microscopic observation and without knowledge of the clinical data for each patient. Cases of disagreement were reviewed jointly to reach a consensus score. The score was the average from 10 distinct high-power fields observed under $\times 400$ magnification. As positive controls we used both a placenta section previously known to be TIMP-3 immunoreactive (external control) as well as normal ductal epithelial cells and in situ components adjacent to cancer tissues (internal staining control). These in particular stained with high intensity, comparable to that of the external staining control. Negative controls had the primary antibody omitted and replaced by nonimmune normal serum from the same species as the primary antibody or by Tris-buffered saline.

TIMP-3 was detected in the cytoplasm of the malignant cells and the peritumoral stroma. Staining intensity and the number of stained cells were taken into consideration all through the evaluation process, and cytoplasmic staining in tumor cells and the peritumoral fibroblasts was scored on a scale of 0 to 3 in half steps, as described previously [28]. A score of 0 was given when no staining was detected, 1 if there was weak to moderate staining in less than $10 \%$ of cells, 2 if moderate to strong staining was present in 11 to $50 \%$ of cells, and 3 if strong staining in more than $50 \%$ of cells was detected. TIMP3 was strongly expressed in internal positive controls. TIMP-3 protein staining in tumor cells fell into two distinct groups: those with expression equal to or reduced in relation to the internal positive staining controls. Tumor TIMP-3 staining was separated into these categories for the purposes of statistical analysis.

Staining for ER and PR was evaluated semiquantitatively with the $\mathrm{H}$ score system; a score of more than 50 was considered positive for both antigens [29]. Evaluation of the immunostaining of p53, c-erbB-2, Ki67 and topolla proteins was performed as described previously [30,31]. Because topoll $\alpha$ immunopositive cells were rare, the percentage of 500 neoplastic cells that were positive for topoll $\alpha$ was determined by image analysis [30]. 
Figure 2

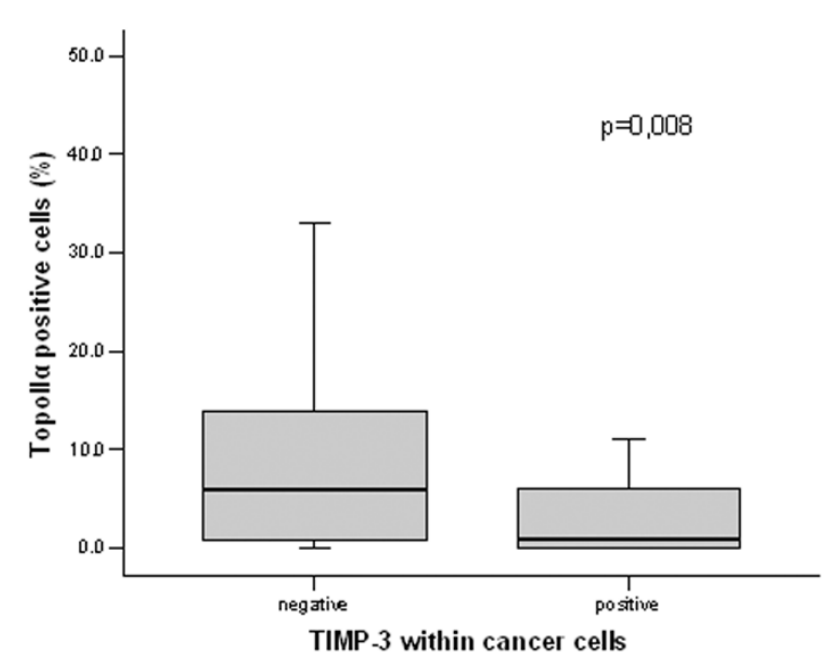

Relation between the expression of TIMP-3 and topoll $\alpha$ proteins. Graphic representation of the relationship between tissue inhibitor of metalloproteinases (TIMP)-3 in cancer cells and topoll $\alpha$ protein expressions.

\section{Statistics}

The significance of the relationship between the expression of TIMP-3 and clinicopathological parameters was evaluated by univariate analysis with a $\chi^{2}$ test and Fisher's exact probability test. Topoll $\alpha$ expression failed to fit the Gaussian distribution. We therefore used nonparametric analysis of variance with ranks to assess the relationship of the aforementioned markers to topolla. The effect of TIMP-3 differential expression on postoperative survival rates was assessed with both univariate (log-rank test) and multivariate (stepwise forward Cox's proportional-hazards regression model) analysis; $p \leq 0.05$ was considered statistically significant.

\section{Results}

TIMP-3 protein was immunodetected in the cytoplasm of the malignant cells and the peritumoral fibroblasts in $35.9 \%$ and $56.4 \%$ of cases, respectively (Figure $1 \mathrm{a}, \mathrm{b}$ ). In the cases where in situ carcinoma or normal epithelium were present, they demonstrated an intense immunopositivity for TIMP-3 (Figure 1c, d). Reduced expression of cancerous TIMP-3 protein was correlated with carcinomas of high nuclear and histological grades ( $p=0.032$ and $p=0.015$, respectively). Moreover, TIMP-3 expression was weakly associated with ER expression ( $p=0.053$ ), whereas no correlation was found between cytoplasmic TIMP-3 and the rest of the clinicopathological parameters (Table 1). Tumor-cell-associated TIMP-3 was inversely correlated with p53 $(p=0.002)$ and topoll $\alpha(p$ $=0.008$, Figure 2), and was positively correlated with Bcl-2 expression $(p=0.020)$. No correlation between TIMP-3 and cerbB-2 status was observed (Table 1 ).
With regard to patient outcome, reduced TIMP-3 expression within cancer cells was weakly correlated with reduced recurrence-free survival in the overall patient population by univariate analysis ( $p=0.052$; Figure 3a). Moreover, reduced TIMP3 in cancer cells was associated with reduced recurrence-free survival in the 100 lymph-node-positive cases ( $p=0.007$; Figure $4 \mathrm{a}$ ) and in the subset of 118 p53-negative cancers $(p=$ 0.037; Figure 4b). However, cancer-cell-associated TIMP-3 was not prognostic for disease-specific overall survival in the entire patient population (Figure 3b) or in any patient subset (data not shown). Nor was TIMP-3 prognostic after multivariate analysis. Indeed, only tumor stage was an independent indicator for recurrence-free (hazard ratio 4.0, 95\% confidence interval 2.3 to $7.1, p<0.0001$ ) or disease-specific overall survival (hazard ratio 5.0, 95\% confidence interval 2.5 to $10.1, p<0.0001$ ) after adjusting for age, therapy received and all other factors listed in Table 1. Unlike cancer-cell-associated TIMP-3, TIMP-3 expression within fibroblasts had no prognostic power (data not shown), nor was it associated with any clinicopathological factor (Table 1).

\section{Discussion}

This is the first immunohistochemical study investigating the clinicopathological and prognostic significance of the various localizations of TIMP-3 protein expression. In the present study, TIMP-3 protein was immunodetected in the cytoplasm of both malignant cells and peritumoral fibroblasts. This is consistent with studies that reported the same localizations in esophageal [17], colorectal [19] and endometrial cancers [20]. Moreover, the fact that we detected TIMP-3 protein in a larger percentage of cases in the peritumoral fibroblasts than in malignant cells agrees with Byrne and colleagues [22] who, by in situ mRNA hybridization, found TIMP-3 gene to be predominantly expressed by fibroblastic cells within the tumor stroma. Furthermore, we found TIMP-3 protein to be expressed in both normal epithelium and the in situ component, where they existed adjacent to the cancerous tissue. This is consistent with the observation of Darnton and colleagues [17], who immunodetected TIMP-3 in normal and metaplastic esophageal epithelium as well as in esophageal adenocarcinoma.

In the present study, reduced expression of TIMP-3 protein was correlated with tumors of higher nuclear and histological grades; in other words, tumors of poor differentiation that usually display a more aggressive biological behavior. This is the first study to report a relationship between TIMP-3 expression and the grade of tumor differentiation. To our knowledge, only two other studies have investigated TIMP-3 expression in breast cancer $[23,24]$ and they found no correlation with any clinicopathological parameter. This discrepancy from our findings may be assigned to the different methodology used. Specifically, both groups of authors used polymerase chain reaction to assess TIMP-3 mRNA expression levels in tumor 

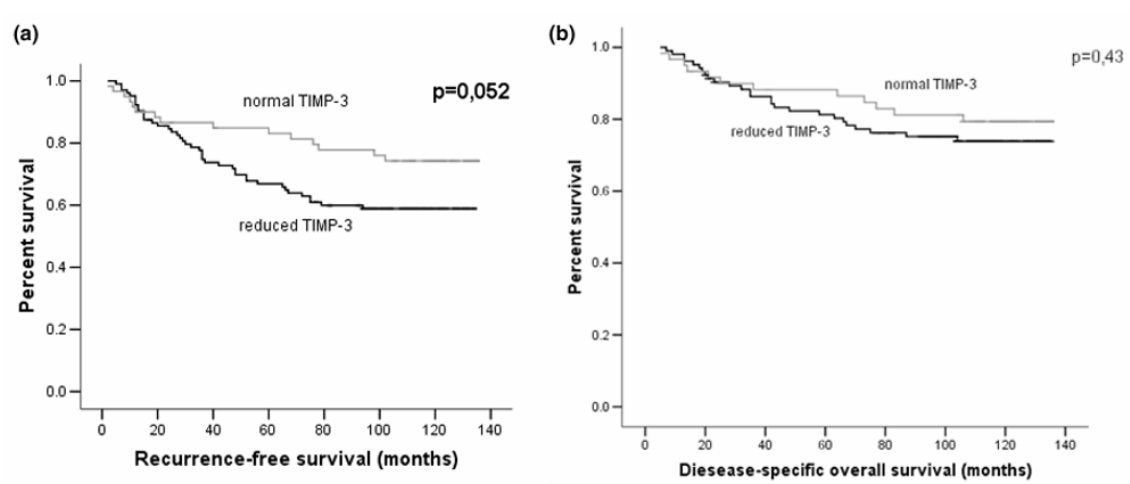

The prognostic significance of TIMP-3 protein expression in the entire patient population. The graphs show the effect of tissue inhibitor of metalloproteinases (TIMP)-3 expression on patient recurrence-free (a) and disease-specific overall (b) survival (log-rank test).

\section{Figure 4}

(a) Lymph nodes positive

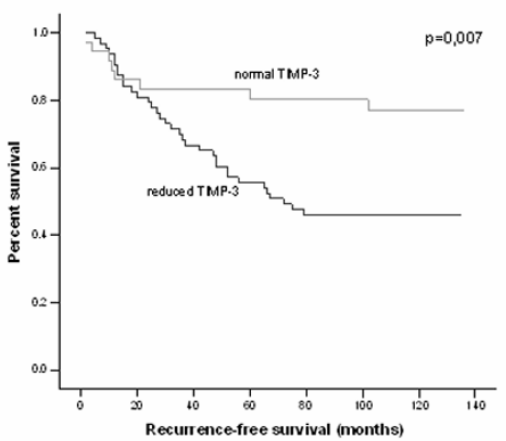

(b) $\quad$ 53 negative

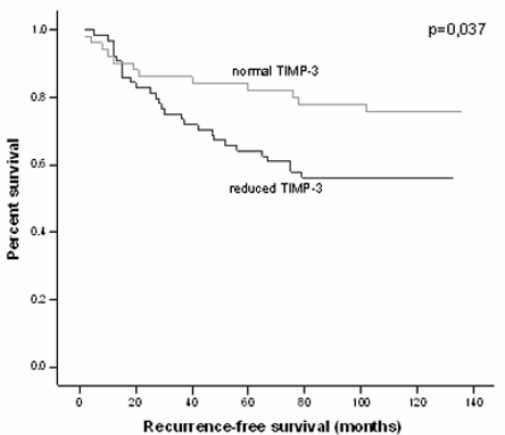

The prognostic significance of TIMP-3 protein expression in the $\mathrm{LN}^{+}$and p53 patient subgroups. The graphs show the impact of tissue inhibitor of metalloproteinases (TIMP)-3 on the recurrence-free survival of the lymph-node (LN)-positive (a) and mutant-p53-negative (b) patients (log-rank test).

tissue, without distinguishing whether mRNA comes from the malignant cells or the surrounding stromal cells.

The aforementioned association of the reduced expression of TIMP-3 protein with an aggressive tumor phenotype is further supported by its correlation with the expression of the mutant p53 and topoll $\alpha$ proteins. The wild-type gene encoding p53 is a tumor suppressor gene whose protein product regulates the cell cycle checkpoint in response to DNA damage [32]. Mutations in this gene, which deactivate its growth-suppressing activities, have been observed in most human tumors. Here it is considered to participate not only in the acquisition of the transformed phenotype but also in the process of cancer progression from benign to metastatic [33]. The inverse correlation between TIMP-3 protein expression and mutant p53 is consistent with the studies that have shown that expression of the gene encoding TIMP-3 is repressed in cells expressing mutant p53 alleles [6].

Topoll $\alpha$ is a proliferation marker that is considered to estimate the number of actively cycling cells [34]. The inverse associa- tion of TIMP-3 protein with a proliferation marker is in line with its inverse correlation with nuclear grade, because the number of mitoses is coevaluated in the assessment of tumor's nuclear grade. Moreover, it agrees with studies that have shown TIMP3 overexpression to inhibit the increase in cell number in vitro $[7,11]$. In other words, according to our findings, reduced TIMP-3 expression seems to be related to cell cycle deregulation and tumor cell proliferation, further contributing to the development of an aggressive tumor phenotype.

$\mathrm{Bcl}-2$ is a negative regulator of apoptosis-specific mitochondrial functions [35]. In the present study we found a positive correlation between TIMP-3 protein expression and the antiapoptotic index Bcl-2, thus suggesting the involvement of TIMP-3 protein in apoptosis suppression. Contrary to our findings, TIMP-3 has been shown to promote apoptosis $[8,9,11$ 13] in an MMP-independent mechanism [11]. However, and in accordance with our findings, TIMP-3/- mice have been shown to display accelerated postlactational epithelial cell apoptosis [14], suggesting that the presence of TIMP-3 in the mammary gland is presumably associated with reduced apoptosis. 
Moreover, in the present study we discovered a positive correlation between TIMP-3 protein within cancer cells and ER. This finding is in line with that of Span and colleagues [23] and Kotzsch and colleagues [24], who also reported TIMP-3 mRNA levels to be higher in steroid hormone receptor-positive samples, and yet not in accord with other studies that demonstrated that estradiol induced a decrease in TIMP-3 in uterine tissue [36] or nulliparous murine mammary gland [37].

As regards survival rate, decreased expression of TIMP-3 within the cytoplasm of cancer cells was associated with poor disease-free survival of our patients. This is in accord with the observation that overexpression of TIMP-3 in tumor cells inhibits invasion, a function consistent with its role as an MMP inhibitor, and induces apoptosis in vitro [8,9]. Our finding was of weak statistical significance and failed to be confirmed in multivariate analysis, differing from both Span and colleagues [23], who found no prognostic significance for TIMP-3 mRNA levels, and Kotzsch and colleagues [24], who showed low TIMP-3 mRNA levels to be an independent poor prognosticator of patient disease-free survival. This may be due to the differences in the methods used or it may reflect the weak rather than the strong prognostic power of TIMP-3 and the modest number of cases examined. However, in subgroup analyses, decreased immunoexpression of TIMP-3 protein was found to be a significant prognostic indicator of an unfavorable recurrence-free survival in both subgroups of lymph-node-positive and mutant-p53-negative patients. This probably suggests that TIMP-3, as an invasion suppressor, may have a major role in patients with positive lymph nodes in whom the invasive process has been already activated. Moreover, the fact that in our study TIMP-3 was weakly associated with outcome but was fairly strongly associated with p53 status, in combination with the studies suggesting that p53 suppresses TIMP-3 expression, makes one think that TIMP- 3 association with outcome may merely be a reflection of p53 status rather than any causal effects that it might have on cancer progression. In other words, p53 may be driving both progression and tumorassociated TIMP-3 expression. However, it is notable that TIMP-3 was still prognostic in the p53-negative subset of cases, suggesting that its correlation with outcome may not merely reflect p53 status but may indeed have an active role in suppressing cancer progression.

Finally, the fact that TIMP-3 protein within fibroblasts was found to have no clinicopathological or prognostic value indicates that, at least in our series of tumor samples, TIMP-3 within cancer cells seems to be more strongly correlated with tumor biological behavior than stromal TIMP-3. Besides, although TIMP-3 has been shown to be bound to the extracellular matrix, to our knowledge there are no studies to elucidate the locations at which TIMP-3 protein takes action.

\section{Conclusion}

This is the first immunohistochemical study to show that, of the two tissue localizations of TIMP-3 protein, cancer and stromal, the one within the cancer cells seems to have a more active role in the modulation of tumor phenotype. Thus, decreased expression of TIMP-3 protein within cancer cells seems to be associated with an aggressive tumor phenotype through its correlations with nuclear and histological grade, expression of the proliferation marker topoll $\alpha$ and expression of the apoptosis-related indicators, mutant p53 and Bcl-2. Moreover, reduced expression of TIMP-3 was found to be a significant prognostic indicator of shortened disease-free survival in the lymph-node-positive and mutant-p53-negative patients, indicating that immunodetection of TIMP-3 protein could improve the prediction of disease recurrence in some subgroups of patients with invasive breast cancer.

\section{Competing interests}

The authors declare that they have no competing interests.

\section{Authors' contributions}

EM participated in the design of the study, carried out the immunohistochemical method, performed the statistical analysis and drafted the manuscript. CM and GA classified the invasive carcinomas and carried out the evaluation of the immunohistochemical staining. IG and LN participated in the design and the coordination of the study. SM and AK collected the human tissue. All authors read and approved the final manuscript.

\section{Acknowledgements}

We are grateful to $S$. Koulyra for editing the manuscript. The project is cofinanced within Op. Education by the ESF (European Social Fund) and National Resources.

\section{References}

1. Freije J, Balbin M, Pendas AM, Sanchez LM, Puente XS, LopezOtin C: Matrix metalloproteinases and tumor progression. Adv Exp Med Biol 2003, 532:91-107.

2. Fassina G, Ferrari N, Brigati C, Benelli R, Santi L, Noonan DM, Albini A: Tissue inhibitors of metalloproteases: regulation and biological activities. Clin Exp Metastasis 2000, 18:111-120.

3. Jiang Y, Goldberg ID, Shi YE: Complex roles of tissue inhibitors of metalloproteinases in cancer. Oncogene 2002, 21:2245-2252.

4. Yu WH, Yu S, Meng Q, Brew K, Woessner JF Jr: TIMP-3 binds to sulfated glycosaminoglycans of the extracellular matrix. $J$ Biol Chem 2000, 275:31226-31232.

5. Wick M, Bürger C, Brüsselbach $S$, Lucibello $C$, Müller R: A novel member of human tissue inhibitor of metalloproteinases (TIMP) gene family is regulated during $G_{1}$ progression, mitogenic stimulation, differentiation and senescence. J Biol Chem 1994, 269:18953-18960.

6. Loging WT, Reisman D: Inhibition of the putative tumor suppressor gene TIMP-3 by tumor-derived p53 mutants and wild type p53. Oncogene 1999, 18:7608-7615.

7. Baker $A H$, Zaltsman $A B$, George SJ, Newby AC: Divergent effects of tissue inhibitor of metalloproteinase $-1,-2$ or -3 overexpression on rat vascular smooth muscle cell invasion, proliferation and death in vitro. J Clin Invest 1998, 101:1478-1487.

8. Ahonen M, Baker AH, Kahari VM: Adenovirus-mediated gene delivery of tissue inhibitor of metalloproteinases-3 inhibits 
invasion and induces apoptosis in melanoma cells. Cancer Res 1998, 58:2310-2315.

9. Baker AH, George SJ, Zaltsman AB, Murphy G, Newby AC: Inhibition of invasion and induction of apoptotic cell death of cancer cell lines by overexpression of TIMP-3. Br J Cancer 1999, 79:1347-1355

10. Yang TT, Hawkes SP: Role of the 21-kDa protein TIMP-3 in oncogenic transformation of cultured chicken embryo fibroblasts. Proc Natl Acad Sci USA 1992, 89:10676-10680.

11. Bian J, Wang Y, Smith MR, Kim H, Jacobs C, Jackman J, Kung HF, Colburn NH, Sun Y: Characterization of a putative p53 binding site in the promoter of the mouse inhibitor of metalloproteinases-3 (TIMP-3) gene: TIMP-3 is not a p53 target gene. Carcinogenesis 1996, 17:1805-1811.

12. Bond M, Murphy G, Bennett MR, Newby AC, Baker AH: Tissue inhibitor of metalloproteinase-3 induces a Fas-associated death domain-dependent type II apoptotic pathway. J Biol Chem 2002, 277:13787-13795.

13. Smith MR, Kung H, Durum SK, Colburn NH, Sun Y: TIMP-3 induces cell death by stabilizing TNF- $\alpha$ receptors on the surface of human colon carcinoma cells. Cytokine 1997, 9:770-780.

14. Leco KJ, Waterhouse $P$, Sanchez $\mathrm{OH}$, Gowing KL, Poole AR, Wakeham A, Mak TW, Khokha R: Spontaneous air space enlargement in the lungs of mice lacking tissue inhibitor of metalloproteinases-3 (TIMP-3). J Clin Invest 2001, 108:817-829.

15. Ahonen M, Ala-Aho R, Baker AH, George SI, Gernman R, Saarialho-Kere U, Kahari VM: Antitumor activity and bystander effect of adenovirally delivered tissue inhibitor of metalloproteinases-3. Mol Ther 2002, 5:705-715.

16. Bachman KE Herman JG, Corn PG, Merlo A, Costello JF Cavenee WK, Baylin SB, Graff JR: Methylation-associated silencing of the tissue inhibitor of metalloproteinase-3 gene suggests a suppressor role in kidney, brain and other human cancers. Cancer Res 1999, 59:798-802.

17. Darnton SJ, Hardie LJ, Muc RS, Wild CP, Casson AG: Tissue inhibitor of metalloproteinase-3 (TIMP-3) gene is methylated in the development of esophageal adenocarcinoma: loss of expression correlates with poor prognosis. Int J Cancer 2005, 115:351-358

18. Miyazaki T, Kato H, Nakajima M, Faried A, Takita J, Sohda M, Fukai $Y$ Yamaguchi S, Masuda N, Manda R, et al: An immunohistochemical study of TIMP-3 expression in oesophageal squamous cell carcinoma. Br J Cancer 2004, 91:1556-1560.

19. Curran S, Dundas SR, Buxton J, Leeman MF, Ramsay R, Murray IG: Matrix metalloproteinase/tissue inhibitors of matrix metalloproteinase phenotype identifies poor prognosis colorectal cancers. Clin Cancer Res 2004, 10:8229-8234.

20. Tunuguntla R, Ripley D, Sang OX, Chegini N: Expression of matrix metalloproteinase-26 and tissue inhibitors of metalloproteinases TIMP-3 and -4 in benign endometrium and endometrial cancer. Gynecol Oncol 2003, 89:453-459.

21. Karan D, Lin FC, Bryan M, Ringel J, Moniaux N, Lin MF, Batra SK: Expression of ADAMs (a disintegrin and metalloproteases) and TIMP-3 (tissue inhibitor of metalloproteinase-3) in human prostatic adenocarcinoma. Int J Oncol $2003,23: 1365-1371$.

22. Byrne JA, Tomasetto C, Rouyer N, Bellocq JP, Rio MC, Basset P: The tissue inhibitor of metalloproteinases- 3 gene in breast carcinoma: identification of multiple polyadenylation sites and stromal pattern of expression. Mol Med 1995, 1:418-427.

23. Span PN, Lindberg R, Manders P, Tjan-Heijnen VC, Heuvel JJ, Beex LV, Sweep CG: Tissue inhibitor of metalloproteinase expression in human breast cancer: TIMP-3 is associated with adjuvant endocrine therapy success. J Pathol 2004, 202:395-402.

24. Kotzsch M, Farthmann J, Meye A, Fuessel S, Baretton G, Tjan-Heijnen VC, Schmitt M, Luther T, Sweep FC, Magdolen V, et al.: Prognostic relevance of UPAR-del4/5 and TIMP-3 mRNA expression levels in breast cancer. Eur J Cancer 2005, 41:2760-2768.

25. Tavassoéli FA, Devilee P: Pathology and Genetics: Tumors of the Breast and Female Genital Organs Lyon: WHO Press; 2003. IARC WHO Classification of Tumours, No. 4.

26. Robins $P$, Pinder $S$, de Klerk N: Histological grading of breast carcinomas: a study of interobserver agreement. Human Pathol 1995, 6:873-879.
27. Union International Contre Cancer: TNM Classification of International Union against Cancer. In TNM Atlas, 3rd revision 4th edition. Edited by: Hermanek P, Sabin H. Berlin: Springer-Verlag; 1992:15-25.

28. Laskawi $\mathrm{NH}$, Wahlers $\mathrm{A}$, Hemmerlein B: Expression of matrix metalloproteinases MMP-2, MMP-9 and tissue inhibitors TIMP$1,-2$, and -3 in benign and malignant tumours of the salivary gland. Histopathology 2004, 44:222-231.

29. McCleilland RA, Wilson D, Leake R, Finlay P, Nicholson RI: A multicentre study into the reliability of steroid receptor immunocytochemical assay quantification. Eur J Cancer 1991, 27:711-716.

30. Nakopoulou L, Lazaris AC, Kavantzas N, Alexandrou P, Athanassiadou $P$, Keramopoulos A, Davaris P: DNA topoisomerase II- $\alpha$ immunoreactivity as a marker of tumor aggressiveness in invasive breast cancer. Pathobiology 2000, 68:137-143.

31. Nakopoulou L, Stefanaki K, Panayotopoulou E, Giannopoulou I, Athanassiadou P, Gakiopoulou-Givalou H, Louvrou A: Expression of the vascular endothelial growth factor receptor-2/Flk-1 in breast carcinomas: correlation with proliferation. Hum Pathol 2002, 33:863-870.

32. Vogelstein B, Lane D, Levine AJ: Surfing the p53 network Nature 2000, 408:307-310.

33. Vousden $\mathrm{KH}$, Prives $\mathrm{C}: \mathrm{p53}$ and prognosis: new insights and further complexity. Cell 2005, 120:7-10.

34. Lynch BJ, Guinee DG Jr, Holden JA: Human DNA topoisomerase II- $\alpha$ : a new marker of cell proliferation in invasive breast cancer. Hum Pathol 1997, 28:1180-1188.

35. Adams JM, Cory S: Life-or-death decisions by the $\mathrm{Bcl}-2$ protein family. Trends Biochem Sci 2001, 26:61-66.

36. Nothnick WB, Zhang X, Zhou HE: Steroidal regulation of uterine edema and tissue inhibitors of metalloproteinase (TIMP)-3 messenger RNA expression is altered in TIMP-1 deficient mice. Biol Reprod 2004, 70:500-508.

37. Fata JE, Chaudhary V, Khokha R: Cellular turnover in the mammary gland is corrected with systemic levels of progesterone and not $17 \beta$-estradiol during the estrous cycle. Biol Reprod 2001, 65:680-688. 